\title{
Acetylated Lipoproteins Impair Erythroid Growth Factor Release from Endothelial Cells
}

\author{
Nicholas Dainiak," Henry B. Warren,‡ Sandra Kreczko," M. Alice Riordan," Laurie Feldman, \\ Jack Lawler, * Amos M. Cohen, ${ }^{\star}$ and Peter F. Davies ${ }^{\star}$ \\ *Departments of Medicine and Biomedical Research, St. Elizabeth's Hospital, Department of Medicine, \\ Tufts University School of Medicine, and ${ }^{\ddagger}$ Division of Vascular Research, Department of Pathology, \\ Brigham and Women's Hospital, Harvard Medical School, Boston, Massachusetts 01235
}

\section{Abstract}

Endothelial cells are a known source of hematopoietic growthenhancing factors, including platelet-derived growth factor (PDGF). In addition, endothelium interacts directly with plasma lipoproteins which have been shown to modulate hematopoiesis. To determine the relationship of these properties, we measured the release of an erythroid growth-enhancing factor from bovine endothelial cells under lipid-loaded and control conditions. Human bone marrow cells cultured under serum-free conditions form more erythroid, granulocyte/macrophage, and mixed hematopoietic colonies when supplemented with endothelial cell-conditioned medium (ECCM) than do controls $(P<0.05)$. The activity is expressed over a wide range of erythropoietin, lymphocyte-conditioned medium (LCM), recombinant human interleukin-3, and colony-stimulating factor (CSF) concentrations, and is related to ECCM dose. In contrast, enhancing activity in ECCM prepared with $0-400 \mu \mathrm{g} / \mathrm{ml}$ acetylated low density lipoproteins (AcLDL) or native $\mathrm{LDL}$ is diminished to $0 \%$ in a dose-dependent fashion (relative to ECCM from unexposed cells or from cells incubated with very low density lipoproteins, $P<0.05$ ). Upon dilution, medium prepared from cells incubated with LDL shows a rightward shift in the dose-response curve for erythroid colony formation, while that prepared from AcLDL loaded cells demonstrates a downward shift, indicating that the inhibitory activities are kinetically distinct. Delipidation of ECCM prior to addition to marrow culture removes the inhibitory action of native LDL $(P<0.05)$ but not that of AcLDL $(P$ $>$ 0.10). Immunochemical analysis suggests that the erythropoietic activity in ECCM is unrelated to that of PDGF, recombinant human CSF, and erythroid burst-promoting activity (BPA) present in LCM. This conclusion is supported by Northern blot analysis of endothelial cells using a cDNA probe for the v-sis homologue of the PDGF $\beta$ chain and by immunoprecipitation of metabolically labeled PDGF. The relative amounts of c-sis transcripts and of secreted PDGF were simi-

This work was presented in part at the 15th Annual Meeting of the International Society of Experimental Hematology, Buffalo, NY, August 1986.

Address reprint requests to Dr. Dainiak, Departments of Medicine and Biomedical Research, St. Elizabeth's Hospital, 736 Cambridge Street, Boston, MA 02135.

Received for publication 5 February 1987 and in revised form 25 September 1987.

J. Clin. Invest.

(c) The American Society for Clinical Investigation, Inc.

$0021-9738 / 88 / 03 / 0834 / 10 \$ 2.00$

Volume 81, March 1988, 834-843 lar in endothelial cells incubated with or without AcLDL. We conclude that AcLDL impair the synthesis or release of an erythropoietic growth-enhancing factor(s) which is biologically distinct from PDGF and BPA present in LCM.

\section{Introduction}

The vascular endothelium is an integral component of human bone marrow stroma that is located in close apposition to developing hematopoietic cells (1). Endothelial cells have been implicated as a source of hematopoietic growth-enhancing molecules, including colony-stimulating activity $(2,3)$ and a factor(s) that promotes the formation of erythroid and mixed granulocyte-erythroid-monocyte-megakaryocyte (GEMM) ${ }^{1}$ colonies in vitro $(4,5)$. In addition, endothelial cells give rise to several mitogens for smooth muscle cells, 3T3 cells, fibroblasts, and glial cells (6-9) that are collectively termed endothelial cell-derived growth factors (EDGFs). Recently, DiCorleto and Bowen-Pope (10) have shown that one of these factors derived from bovine aortic endothelial cells is a platelet-derived growth factor (PDGF)-like protein. They have also suggested that production of this factor which binds to the receptor for PDGF may be suppressed by intracellular cholesterol accumulation induced by exposure to oxidized acetylated low density lipoproteins (AcLDL) $(11,12)$.

We have previously shown that PDGF prepared from human platelets is a determinant of optimal erythroid progenitor cell proliferation in marrow culture (13). Rather than stimulating erythroid progenitors directly, PDGF is believed to augment erythropoiesis in vitro via an effect on mesenchymal cells, which in turn enhance colony formation (14). In this communication, we have probed the relationship of endothelial cell-derived erythroid enhancing factors and PDGF-like proteins by examining whether or not exposure of endothelium to AcLDL alters the secretion of erythroid growth factors that are assayable under serum-free conditions. We have found that AcLDL inhibit the expression of an erythroid enhancing molecule in a fashion that is kinetically distinct from the inhibitory action of native LDL and is the result of im-

1. Abbreviations used in this paper: AcLDL, acetylated low density lipoproteins; BAEC, bovine aortic endothelial cells; BFU-E, burstforming unit-erythroid; BPA, erythroid burst-promoting activity; CFU-E, colony-forming unit-erythroid; CFU-GEMM, colony-forming unit-granulocyte, erythrocyte, macrophage, megakaryocyte; CFU-G/ $M$, colony-forming unit-granulocyte/macrophage; ECCM, endothelial cell-conditioned medium; GM-CSF, granulocyte/macrophage colonystimulating factor; LCM, lymphocyte conditioned medium; NC, nitrocellulose membrane; PDGF, platelet-derived growth factor; PHEC, passaged human endothelial cells. 
paired growth factor release from endothelial cells into liquid culture medium.

\section{Methods}

Cholesterol loading of endothelial cells. Passaged bovine aortic endothelial cells, designated BAEC, were obtained by collagenase digestion and maintained in Dulbecco's modified Eagle's medium (DME) supplemented with $10 \%$ heat-inactivated calf serum, L-glutamine (200 $\mathrm{mM})$, penicillin $(25,000 \mathrm{U} / \mathrm{ml})$, and streptomycin $(25,000 \mu \mathrm{g} / \mathrm{ml})$ (Gibco, Grand Island, NY). Passaged human endothelial cells (PHEC) were isolated by standard techniques and maintained in the presence of endothelial growth factor (Malloy Laboratories, Springfield, VA) and heparin according to the methods of Thornton et al. (15). Cells were grown on tissue culture plastic (100-mm Costar dishes) and used in experiments before $25^{\mathrm{TH}}$ subculture from primary isolation for BAEC, and before $6^{\mathrm{TH}}$ subculture for PHEC. Endothelial cell-conditioned medium (ECCM) was prepared by washing cell monolayers with serum-free Hanks' balanced salt solution several times and incubating cells in DME as described except that the serum concentration was reduced to $0.4 \%$ lipoprotein-deficient serum (or, for biochemical analysis, to $0 \%$ serum), and that native or acetylated lipids were added as described below. At the conclusion of 24 or $48 \mathrm{~h}$, the medium was harvested, centrifuged at $1,000 \mathrm{~g}$ for $5 \mathrm{~min}$, and stored at $-20^{\circ} \mathrm{C}$ until use.

Human low density lipoproteins (LDL; density, 1.019-1.063) and very low density lipoproteins (VLDL; density, 0.94-1.006) were isolated by heparin-manganese precipitation from recovered plasma (American Red Cross, Needham, MA) as described previously (16), followed by assessment of purity by double radial immunodiffusion. The amino groups on the LDL were acetylated by reaction with acetic anhydride following the method of Fraenkel-Conrat (17), and the changed electrophoretic mobility of the AcLDL was verified on agarose gels (18). Cholesterol measurements were made on sonicated isopropanol extracts of cell monolayers by fluorometric assay (19).

Endothelial cells were incubated with LDL, VLDL, or AcLDL $(100-400 \mu \mathrm{g} / \mathrm{ml})$ added to base medium. All media were centrifuged at $15,600 \mathrm{~g}$ for $1 \mathrm{~min}$ in an Eppendorf Microfuge (Brinkmann Instruments, Westbury, NY) prior to addition to bone marrow culture. In some cases, ECCM was first concentrated fivefold by pressure filtration (Amicon Corp., Danvers, MA).

Mitogenic activity assay. DNA synthesis was measured by autoradiography of incorporated $\left[{ }^{3} \mathrm{H}\right]$ thymidine. Cultures were incubated with $0.1 \mu \mathrm{Ci} / \mathrm{ml}$ (6-7 Ci/mmol, New England Nuclear, Boston, MA) for $20 \mathrm{~h}$ at times indicated. The cells were processed for autoradiography of labeled DNA, as previously described (14).

Delipidation of ECCM. Solid $\mathrm{KBr}(7.5 \%)$ was added to ECCM prepared in the presence and absence of LDL, AcLDL, or VLDL. ECCM was centrifuged at $123,000 \mathrm{~g}, 20 \mathrm{~h}, 10^{\circ} \mathrm{C}$ and $2-\mathrm{mm}$ cuts of the supranates and infranates were made. Test and control medium fractions were dialyzed for 12-14 $\mathrm{h}$ against PBS prior to addition to culture. For lipoprotein measurements, $100 \mu \mathrm{l}$ of lipid-containing ECCM or lipid-depleted ECCM were mixed with $100 \mu$ l of Sudan black solu-

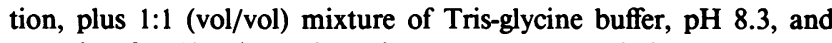
glycerine for $60 \mathrm{~min}, 37^{\circ} \mathrm{C}$ prior to electrophoresis in $3.5 \%$ acrylamide (20).

Serum-free culture of hematopoietic progenitor cells. Approximately $0.5 \mathrm{ml}$ of well-spiculated bone marrow was aspirated from the posterior iliac crest of healthy, paid donors. Informed consent was obtained prior to each donation, and approval of an institutional review board was granted prior to initiation of this study. Using sterile technique, the aspirate was placed into Eagle's minimal essential medium (MEM) (Gibco) containing preservative-free heparin and separated over Ficoll-Paque (Pharmacia Fine Chemicals, Piscataway, NJ) at $4^{\circ} \mathrm{C}$. Mononuclear cells appearing at the interface were carefully removed, washed three times in MEM without heparin, and cultured at a density of $2 \times 10^{4}$ to $2 \times 10^{5} / \mathrm{ml}$. In some cases, marrow cells were further separated as previously described $(21)$ by adherence to polysty- rene, $90 \mathrm{~min}, 37^{\circ} \mathrm{C}$; followed by rosette formation with sheep red blood cells to remove $\mathrm{T}$ cells, and by indirect panning with mouse anti-human B4 antibody $\left(100 \mu \mathrm{g} / \mathrm{ml}, 30 \mathrm{~min}, 4^{\circ} \mathrm{C}\right)$ to remove B cells. Unseparated cells and depleted marrow cells were cultured as described below.

Serum-free marrow cultures were established in fibrin clots as described previously (20). They contained Iscove's modified Dulbecco's medium (IMDM) (Gibco), highly purified, delipidated human serum albumin, saturated ferric chloride/transferrin, and 0-4 U/ml sheep step III erythropoietin (Connaught Laboratories, Ontario, Canada) or recombinant human erythropoietin (70,000-80,000 U/mg, Amgen Biologicals, Thousand Oaks, CA). Test plates contained $10 \% \mathrm{vol} / \mathrm{vol}$ nonmitogenic base medium, ECCM (with or without LDL, VLDL, or AcLDL), and/or lymphocyte-conditioned medium (LCM) (22). In some cases, $10 \%$ purified human or porcine PDGF, human colonystimulating factor (CSF; Hyclone, Logan, UT), recombinant human granulocyte-macrophage (GM)-CSF (Genetics Institute, Cambridge, MA), or recombinant human IL-3 (rHSIL-3; Genetics Institute) was also added at concentrations indicated in the figures and tables. Cultures were maintained at $37^{\circ} \mathrm{C}, 5 \% \mathrm{CO}_{2}$ in humidified air. Colonies consisting of 8-49 benzidine-positive cells appearing after $7 \mathrm{~d}$ were scored as colony-forming unit, erythroid (CFU-E)-derived colonies. Burst-forming unit, erythroid (BFU-E)- and CFU-GEMM-derived colonies were scored on day 12 of incubation. Erythroid bursts consisted of $\geq 50$ nucleated cells that were benzidine positive and mixed hematopoietic colonies consisted of morphologically identifiable granulocytes, erythroblasts (benzidine-positive), macrophages, and megakaryocytes. Granulocyte/macrophage (G/M) colonies consisted of aggregates containing $\geq 50$ cells (21). All colonies were scored under magnification $\times 100$. Cloning efficiency in control cultures was in the range of 20-45 CFU-E-derived colonies, 15-45 BFU-E-derived colonies, 45-65 CFU-G/M-derived colonies, and 10-16 mixed colonies/ $10^{5}$ light density cells plated.

Characterization of ECCM activity. To determine whether the enhancing activity in ECCM competes with stimulatory activity expressed by PDGF, ECCM was added to cultures containing 1-100 ng of highly purified human PDGF (kindly provided by Dr. Thomas Deuel, Washington University Medical Center, St. Louis, MO) or electrophoretically pure porcine PDGF (23; Bethesda Research Labs, Gaithersburg, MD)/ml. In addition, ECCM was incubated at $100^{\circ} \mathrm{C}$ for $10 \mathrm{~min}$ and residual activity was assayed in culture. Finally, ECCM was tested in cultures containing $66 \mu \mathrm{g}$ L-asparagine, 3-mercapto-1,2propanediol/ml, a thiol-containing compound whose reducing action results in inactivation of erythroid enhancing activity expressed by PDGF (13).

ECCM was also tested for enhancing activity in cultures containing LCM, which is known to contain erythroid burst-promoting activity (BPA), rHSIL-3, or recombinant GM-CSF. To further investigate the relatedness of ECCM enhancing activity to BPA and recombinant GM-CSF, attempts were made to immunoprecipitate the growth factor, as described below.

For preparative SDS gel electrophoresis, serum-free bovine ECCM prepared with insulin, transferrin, and selenous acid (ITS, Collaborative Research, Lexington, MA) was concentrated 10 -fold by pressure filtration (Amicon Corp.), and dialyzed against PBS, $\mathrm{pH} 7.2$, for $4 \mathrm{~d}$, $4^{\circ} \mathrm{C}$. The sample was heated to $70^{\circ} \mathrm{C}$ for $10 \mathrm{~min}$ in the presence of $1 \%$ SDS and $20 \mathrm{mM}$ dithiothreitol and electrophoresed on $10 \%$ polyacrylamide gels according to the method of Laemmli (24). The gel was sliced into $1-\mathrm{cm}$ sections and electroluted for $48 \mathrm{~h}$, using the method of Hunkapiller et al. (25). For culture purposes, the eluted samples were supplemented with penicillin and streptomycin and extensively dialyzed as above. Residual SDS in the form of a precipitated salt was removed by centrifugation at $15,600 \mathrm{~g}$ for $30 \mathrm{~s}$ in a Eppendorf microfuge. $100 \mu \mathrm{l}$ of supernatants was added to culture $(10 \%, \mathrm{vol} / \mathrm{vol})$ and eluted activity was assayed under serum-free conditions.

Immunoprecipitation of ECCM. Serum-free ECCM $(200 \mu \mathrm{l})$ was incubated overnight, $4^{\circ} \mathrm{C}$, with $0-200 \mu \mathrm{g}$ of normal rabbit IgG or rabbit anti-human lymphocyte membrane IgG (26). The antimem- 
brane antibody employed cross-reacts with and neutralizes BPA but does not neutralize naturally released human GM-CSF (Hyclone) and does not remove erythropoietic or granulopoietic activity from recombinant human GM-CSF (Genetics Institute) (26a). In additional experiments, $300 \mu \mathrm{l}$ of ECCM diluted as indicated in Table III was incubated overnight, $4^{\circ} \mathrm{C}$, with $300 \mu \mathrm{l}$ of sheep anti-human recombinant GM-CSF antiserum (Genetics Institute) in an amount capable of neutralizing $100 \mathrm{U}$ of recombinant human GM-CSF (27). Antiserum was also incubated with 5-20 U of recombinant GM-CSF or 0.5-10 U of rHSIL-3. For all absorptions, immune complexes plus free IgG were removed from solution by incubation, $30 \mathrm{~min}, 25^{\circ} \mathrm{C}$, with an excess amount of a $20 \%$ staphylococcal protein A solution, and centrifugation at $16,000 \mathrm{~g}, 60 \mathrm{~s}$, or until a visible pellet appeared. $100 \mu \mathrm{l}$ of absorbed supernatants was assayed in culture, and results were compared to activities in cultures concurrently established with $100 \mu \mathrm{l}$ of unabsorbed ECCM, GM-CSF, or IL-3.

Cytoplasmic RNA extraction, sis transcript analysis, and PDGF immunoprecipitation. RNA was prepared following the method of $\mathrm{Fa}$ valoro et al. (28). Lipid-loaded and control cell monolayers of BAEC, PHEC, human osteosarcoma cells, and human dermal fibroblasts were harvested by trypsin digestion. They were then lysed in buffer containing $0.14 \mathrm{M} \mathrm{NaCl}, 1.5 \mathrm{mM} \mathrm{MgCl} 2,10 \mathrm{mM}$ Tris-Cl, $\mathrm{pH} 8.6,0.5 \%$ $\mathrm{NP}-40$, and $10 \mathrm{mM}$ vanadyl ribonucleoside complex (Bethesda Research Labs). Nuclei were removed by centrifugation over a $24 \%$ sucrose cushion and the resulting supernatant was digested with proteinase $\mathrm{K}(100 \mu \mathrm{g} / \mathrm{ml})$ (Bethesda Research Labs). The digested cytoplasmic lysate was extracted with chloroform and phenol (1:1) and precipitated by adding $1.25 \mathrm{vol}$ of isopropyl alcohol and stored at $-20^{\circ} \mathrm{C}$.

The RNA precipitate was pelleted, washed with $70 \%$ ethanol, dried, and hydrated in distilled water. Its mass was determined spectrophotometrically at $260 \mathrm{~nm}$. The integrity of RNA was determined by ethidium bromide staining of electrophoresed $1 \%$ agarose gels containing $0.4 \mathrm{M}$ morpholinopropanesulfonic acid and $0.5 \%$ formaldehyde (29). After photography, the gels were blotted onto nitrocellulose membrane (NC) (Schleicher \& Schuell, Inc., Keene, NH) by standard techniques (30), baked for $1 \mathrm{~h}, 80^{\circ} \mathrm{C}$, in a vacuum oven, and stored at $-20^{\circ} \mathrm{C}$. Dot blots were made following the protocol of White and Bancroft (31). Briefly, aliquots of RNA were denatured by heating in $40 \%$ formaldehyde at $65^{\circ} \mathrm{C}$ for $15 \mathrm{~min}$, serially diluted and blotted onto nitrocellulose under suction.

RNA transcripts specific for the $\beta$ chain of PDGF were identified by hybridization of the immobilized RNA with a nick-translated ${ }^{32} \mathrm{P}$ labeled v-sis DNA probe (obtained from Drs. Aronson and Robbins of the National Cancer Institute) following standard techniques $(29,30)$. $\mathrm{NC}$ membranes were incubated in a prehybridization buffer containing $0.2 \%$ bovine serum albumin (Sigma Chemical Co., St. Louis, MO), $0.2 \%$ ficoll (type 400, Pharmacia Fine Chemicals), $0.2 \%$ polyvinyl pyrrolidone (Sigma Chemical Co.), $5 \times \mathrm{SSC}(1 \times=0.15 \mathrm{M} \mathrm{NaCl}, 0.015 \mathrm{M}$ $\mathrm{Na}$ Citrate), $50 \mathrm{mM} \mathrm{Na} \mathrm{PO}$, pH 6.5, $1 \%$ SDS, 50\% deionized formamide (Bethesda Research Labs), and a 1:4 addition of 50\% Dextran sulfate (Sigma Chemical Co.) at $0.5 \mathrm{ml} / \mathrm{cm}^{2} \mathrm{NC}$ membrane at $42^{\circ} \mathrm{C}$ for 4-18 $\mathrm{h}$. The radiolabeled DNA probe was denatured by boiling and added to prehybridization buffer $\left(0.04 \mathrm{ml} / \mathrm{cm}^{2}\right)$. The hybridization reaction proceeded at $42^{\circ} \mathrm{C}$ for $18 \mathrm{~h}$ after which the membranes were exhaustively washed at high stringency (low salt and $65^{\circ} \mathrm{C}$ ) to remove nonspecific radioactivity. After the final wash, $\mathrm{NC}$ membranes were exposed to Kodak XAR-5 film (Kodak) at $-70^{\circ} \mathrm{C}$.

For immunoprecipitation, cells were grown to confluence after which growth medium was withdrawn and replaced by DME lacking cysteine (Gibco) supplemented with $\left[{ }^{35} \mathrm{~S}\right]$ cysteine $(0.50 \mathrm{mCi} / \mathrm{ml})$ (Amersham Corp.). Medium was conditioned for $18 \mathrm{~h}$, collected, centrifuged ( $500 \mathrm{~g}$ for $5 \mathrm{~min}$ ) to remove cell debris, shell frozen in an acetone/dry ice bath, and lyophilized. This material was rehydrated and dialyzed against immunoprecipitation buffer containing protease inhibitors and precipitated with rabbit anti-human PDGF IgG. The immunoprecipitates were then boiled in SDS and applied to a polyacrylamide gel for electrophoresis, following standard techniques (24). After electrophoresis, the gel was dried and exposed to Kodak XAR-5 film at $-70^{\circ} \mathrm{C}$. Autoradiograms were scanned by laser densitometry (Ultrascan, LKB, Produkter, Bromma, Sweden) and the integrated area under each peak was determined.

Statistical analysis. Mean \pm SE colonies for each of four $125-\mu 1$ fibrin clots were calculated. Data sets were compared by the two-sample ranks test of Wilcoxon and White (32).

\section{Results}

Enhancement of colony formation by ECCM. ECCM prepared from confluent BAEC and PHEC increased $\left[{ }^{3} \mathrm{H}\right]$ thymidine incorporation in confluent growth-arrested cultures of smooth muscle cells in a linear fashion, while base medium was nonmitogenic (data not shown). As shown in Fig. 1, day 7 and 12 erythroid colonies were also increased by undiluted ECCM $(P$ $<0.05$ ). A similar effect was observed on CFU-GEMM and CFU-G/M proliferation (see Table I). The erythroid-enhancing activity peaked or reached a plateau at concentrations greater than $1 x$, and was gradually reduced at concentrations of $\frac{1}{2} x$ and $\frac{1}{4} x$ (see Fig. 1). No erythroid colonies formed in the absence of added erythropoietin, and no mixed colonies formed in the absence of added LCM (see Table I). The erythropoietic effect of ECCM was present at all erythropoietin, LCM, and CSF concentrations tested (Fig. 2). Not only the number but also the size of erythroid colonies and bursts was increased by ECCM. Likewise, $1 X$ ECCM increased the number of G/M colonies formed with 5,10 , or $20 \mathrm{U} / \mathrm{ml}$ recombinant GM-CSF, and the number of mixed hematopoietic colonies formed with $0.5,1.0,2.5$, and $5.0 \mathrm{U} / \mathrm{ml}$ recombinant human IL-3 by two- to threefold at each growth factor concentration $(P<0.05$ for each).

In order to assess the nature of bone marrow cells that are targeted by erythroid enhancing activity, ECCM was assayed in cultures seeded at cell concentrations approaching threshold for the system. Both day 7 and 12 colony numbers were increased in cultures containing $2 \times 10^{4}$ cells $/ \mathrm{ml}$ (data not

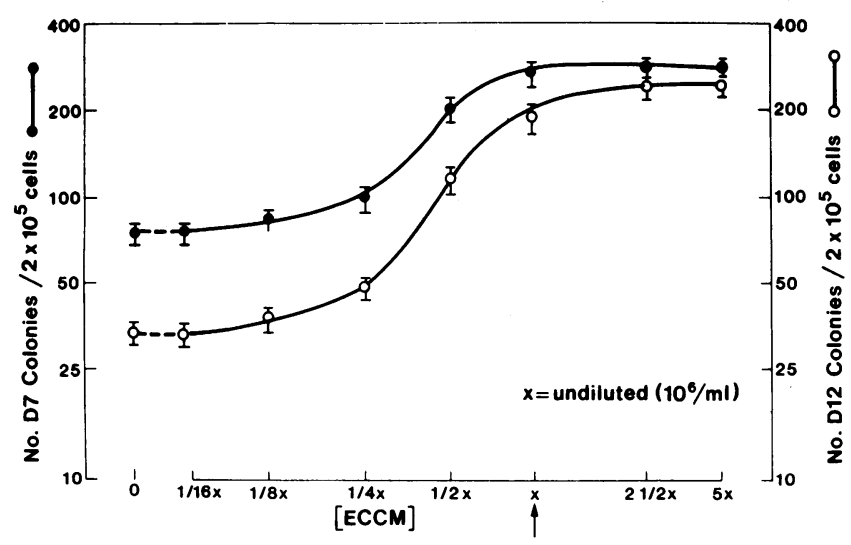

Figure 1. ECCM augments erythroid colony number. Mean \pm SE CFU-E-derived (D7) and BFU-E-derived (D12) colonies are displayed for cultures containing nonmitogenic base medium $(0)$ or $10 \%$ (vol/vol) ECCM prepared from BAEC plus $2.0 \mathrm{U} / \mathrm{ml}$ recombinant erythropoietin. Day $7(\bullet)$ and day $12(0)$ colonies are increased above control $(P<0.05)$ at concentrations of $\frac{1}{4} x, \frac{1}{2} x, x, 2 \frac{1}{2} x$ and $5 x$ (where $x$ refers to undiluted medium conditioned by $10^{6}$ endothelial cells/ml). Colony formation in cultures supplemented with base medium was similar to that in NCTC-109 (Microbiological Associates, Bethesda, MD) containing cultures $(P>0.10)$. Similar results were obtained with ECCM prepared from PHEC. 
Table I. ECCM Effects on CFU-GEMM and $C F U-G / M$ Proliferation

\begin{tabular}{lccc}
\hline & & \multicolumn{2}{c}{ Stimulation } \\
\cline { 3 - 4 } Addition to culture & $\begin{array}{c}\text { Endothelium } \\
\text { treatment }\end{array}$ & Mixed & G/M \\
\hline & & \multicolumn{3}{c}{$\%$} \\
NCTC-109 & - & $100 \pm 15$ & $100 \pm 18$ \\
Base medium alone & - & $104 \pm 7$ & $95 \pm 9$ \\
ECCM & - & $268 \pm 16$ & $204 \pm 10$ \\
ECCM & LDL & $97 \pm 10$ & $86 \pm 12$ \\
ECCM & VLDL & $295 \pm 21$ & $196 \pm 14$ \\
ECCM & AcLDL & $84 \pm 17$ & $85 \pm 17$ \\
& & & \\
\end{tabular}

ECCM was prepared by exposure to bovine endothelium that was incubated with or without $400 \mu \mathrm{g}$ of lipoprotein $/ \mathrm{ml}$. Mean \pm SE stimulation of mixed colony growth is displayed for quadruplicates in cultures containing $2.0 \mathrm{U} / \mathrm{ml}$ sheep erythropoietin plus $10 \%$ (vol/vol) LCM. Mean \pm SE stimulation of granulocyte/macrophage (G/M) colony formation is displayed for triplicates containing human CSF ( 5 $\mathrm{ng} / \mathrm{ml}$ ) plus control medium or ECCM. Results are pooled from three separate studies. Stimulatory activity in ECCM is reduced by preincubation with LDL or AcLDL $(P<0.05$ for each) but not with VLDL $(P>0.10)$. Cultures with $100 \%$ stimulation contained 16 CFU-GEMM-derived and $59 \mathrm{CFU-G/M-derived} \mathrm{colonies} \mathrm{per} \mathrm{clot.}$

shown). Additionally, ECCM enhanced erythroid colony formation in cultures of marrow mononuclear cells depleted of accessory monocytes and lymphocytes (Table II).

Next, anti-CSF antiserum was used in an effort to immunoprecipitate the active ECCM factor(s). As shown in Table III, preabsorption with a recombinant GM-CSF antibody only partially removed erythropoietic but completely removed granulopoietic activity from ECCM. Preabsorption of recombinant GM-CSF removed all granulopoietic activity, while no loss of mixed hematopoietic activity expressed by recombinant human IL-3 was observed (data not shown). Together, the results indicate that ECCM expresses erythropoietic growthenhancing activity that is additive with that of other known hematopoietic growth regulators. This activity which is immunologically distinct from recombinant GM-CSF appears to be directed at erythroid progenitor cells per se, rather than at accessory cells within the bone marrow.

Cholesterol effects on endothelial cells. To assess alterations in bovine and human endothelial cells after exposure to lipid, intracellular cholesterol levels were measured after 1-7 d of incubation. An average elevation in free cholesterol level of $35.6 \%$ above untreated endothelium (range, $7-77 \%$ ) was observed after $24 \mathrm{~h}$. Incubation for up to six additional days in the presence of lipid did not significantly increase lipid content. Phase-contrast microscopy of cholesterol-loaded cells revealed no significant morphologic alterations, regardless of incubation time. In addition, neither total protein content nor endothelial cell number in lipid-containing cultures was different from that of controls. Thymidine autradiography of test and control monolayers appearing 3 and $5 \mathrm{~d}$ after obtaining confluence indicated that $<2 \%$ of the cells were proliferating at each time period. The data indicate that while intracellular cholesterol rises significantly in endothelial cells exposed to lipoproteins, no differences are apparent in the morphology, growth pattern, or cell cycle kinetics of lipid-loaded cells relative to untreated endothelial cells.

Cholesterol effects on growth-enhancing activity. We next prepared marrow cultures with ECCM made by exposure to endothelial cells which had been incubated with lipoproteincontaining medium. Fig. 3 shows that CFU-E-enhancing activity is suppressed by native LDL and AcLDL in a dose-related fashion to levels at or below controls containing nonmitogenic base medium. Furthermore, colony formation in the presence of base medium containing these lipoproteins $(400$

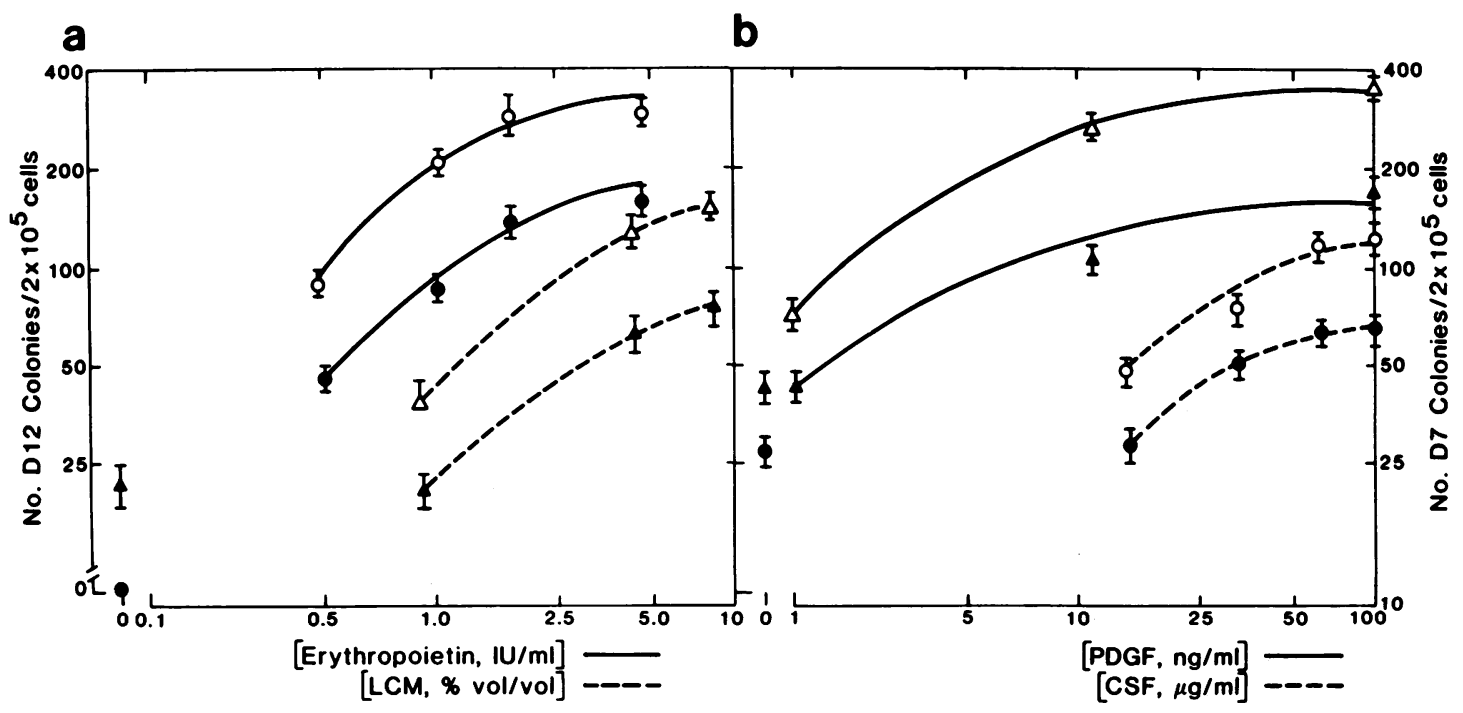

Figure 2. Interactions of ECCM with other hematopoietic growth enhancers. (a) Mean \pm SE CFU-E-derived colonies (D7) (circles) formed with various amounts of erythropoietin, and mean \pm SE BFU-E derived colonies (D12) (triangles) formed with $2.0 \mathrm{IU}$ erythropoietin/ $\mathrm{ml}$ plus various amounts of LCM are shown. Cultures were plated with (open symbols) or without (solid symbols) 10\% (vol/vol) ECCM prepared from BAEC. (b) Mean \pm SE CFU-E-derived colonies (trian-

gles) formed with 2.0 IU erythropoietin plus various amounts of purified human PDGF, and mean \pm SE BFU-E-derived colonies formed with $2.0 \mathrm{IU}$ erythropoietin/ml plus various amounts of human CSF are likewise shown. ECCM (10\% vol/vol) augments colony formation $(P<0.05)$ over the full range of concentrations of each growth factor. Similar results were obtained with purified porcine PDGF (data not shown). 
Table II. ECCM Effects on Erythroid Colony Formation by Fractionated Marrow Mononuclear Cells

\begin{tabular}{lccc}
\hline & & \multicolumn{2}{c}{ Erythroid colonies } \\
\cline { 3 - 4 } \multicolumn{1}{c}{ Mononuclear fraction } & $\begin{array}{c}\text { ECCM } \\
(10 \%, \text { vol/vol })\end{array}$ & \multicolumn{1}{c}{ Day 7} & Day 12 \\
\hline A. Unseparated & - & $100 \pm 10$ & $100 \pm 11$ \\
& + & $218 \pm 15^{*}$ & $236 \pm 12^{*}$ \\
B. Monocyte-depleted & - & $100 \pm 8$ & $100 \pm 11$ \\
& + & $224 \pm 10^{*}$ & $280 \pm 24^{*}$ \\
C. Monocyte, T cell- & - & $100 \pm 8$ & $100 \pm 16$ \\
$\quad$ depleted & + & $195 \pm 10^{*}$ & $245 \pm 13^{*}$ \\
D. Monocyte, T cell-, & - & $100 \pm 11$ & $100 \pm 14$ \\
B cell-depleted & + & $229 \pm 16^{*}$ & $274 \pm 25^{*}$
\end{tabular}

Mean \pm SE stimulation in quadruplicates is displayed for cultures of 2 $\times 10^{4}$ unseparated and depleted marrow cells containing $2.0 \mathrm{IU} / \mathrm{ml}$ erythropoietin. Cell populations were depleted as described in Methods. Note that $1 X$ ECCM prepared from bovine endothelium augments colony formation in each case. Day 7 cultures with $100 \%$ stimulation contained $34(A), 27(B), 22(C)$, and $8(D)$ CFU-E-derived colonies per clot. Day 12 cultures with $100 \%$ stimulation contained $18(A), 24(B), 19(C)$, and $11(D)$ BFU-E-derived colonies per clot.

* Significance between cultures without $(-)$ and with (+) ECCM, $P$ $<0.05$.

$\mu \mathrm{g} / \mathrm{ml}$ ) was reduced below that in the presence of base medium alone, although the magnitude of the inhibitory effect was diminished relative to that observed with ECCM (see Fig. 3). In contrast, exposure of endothelial cells to VLDL did not alter

Table III. Influence of Absorption of ECCM with Anti-GM-CSF Antiserum on Colony Stimulatory Activity

\begin{tabular}{cccc}
\hline & \multicolumn{2}{c}{ Erythroid } & \\
\cline { 2 - 3 } ECCM & Day 7 & Day 12 & $\begin{array}{c}\text { Granulocyte/ } \\
\text { macrophage }\end{array}$ \\
\hline None & $100 \pm 9$ & $100 \pm 6$ & $100 \pm 7$ \\
Unabsorbed & & & \\
$X$ & $264 \pm 8$ & $353 \pm 8$ & $214 \pm 11$ \\
$1 / 2 X$ & $218 \pm 10$ & $295 \pm 15$ & $176 \pm 9$ \\
$1 / 4 X$ & $165 \pm 10$ & $186 \pm 13$ & $142 \pm 10$ \\
$1 / 8 X$ & $114 \pm 9$ & $127 \pm 11$ & $109 \pm 11$ \\
$1 / 32 X$ & $99 \pm 7$ & $106 \pm 12$ & $113 \pm 10$ \\
Absorbed & & & \\
$X$ & $231 \pm 14^{*}$ & $307 \pm 15^{*}$ & $103 \pm 9^{*}$ \\
$1 / 2 X$ & $170 \pm 15^{*}$ & $258 \pm 10^{*}$ & $111 \pm 10^{*}$ \\
$1 / 4 X$ & $126 \pm 13^{*}$ & $135 \pm 10^{*}$ & $102 \pm 8^{*}$ \\
$1 / 8 X$ & $96 \pm 9$ & $103 \pm 7^{*}$ & $99 \pm 10$ \\
$1 / 32 X$ & $105 \pm 8$ & $104 \pm 1$ & $101 \pm 7$ \\
& & & \\
& & &
\end{tabular}

Mean \pm SE stimulation of colony formation is displayed for quadruplicates in cultures prepared as described in legend to Table I. 10\% (vol/vol) unabsorbed ECCM prepared from PHEC and ECCM preabsorbed with sheep anti-human recombinant GM-CSF antiserum was tested, and results were compared at each dilution. Cultures with $100 \%$ stimulation contained 44 CFU-E-derived, 21 BFU-E-derived, and 52 CFU-G/M-derived colonies per clot. * Significance between samples with unabsorbed and preabsorbed ECCM, $P<0.05$.

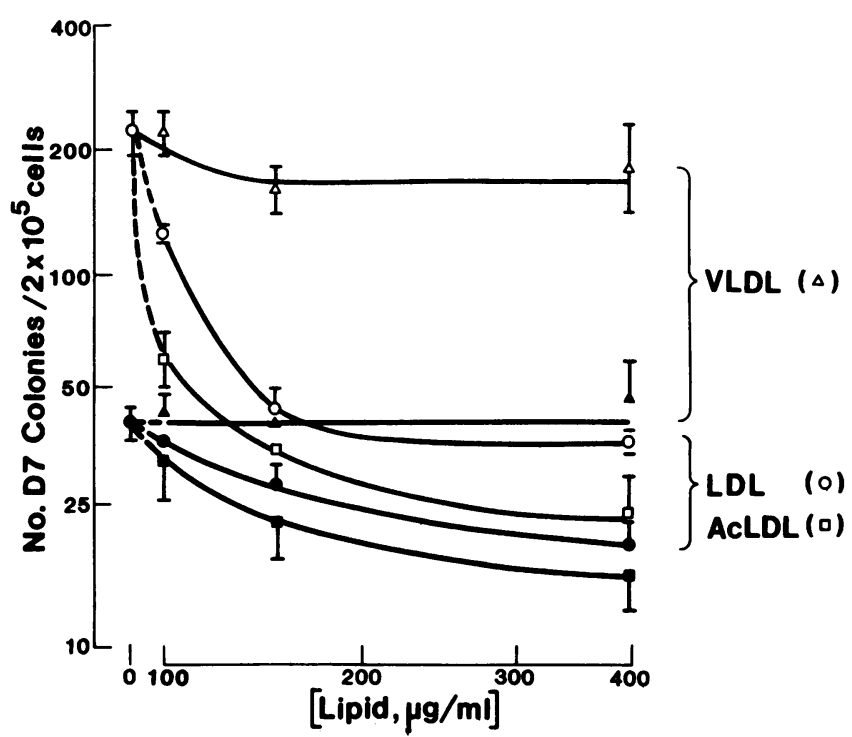

Figure 3. Lipid effects on ECCM activity. Mean \pm SE CFU-E-derived colonies are displayed for cultures containing $10 \%$ (vol/vol) base medium (solid symbols) or ECCM (open symbols) prepared from BAEC that were incubated with and without (0) LDL (circles), AcLDL (squares), or VLDL (triangles) at the indicated concentrations. Control plates contained ECCM prepared in the absence of lipid (0). Marrow cultures contained $2.0 \mathrm{U} / \mathrm{ml}$ sheep erythropoietin. Similar results were obtained in day 12 cultures (BFU-E-derived colonies), and with ECCM prepared from PHEC.

the expression of enhancing activity. Similar lipid effects were observed in assays for CFU-GEMM proliferation (see Table I) and BFU-E proliferation (data not shown). Therefore, both native and acetylated forms of LDL suppress hematopoietic growth factor expression.

To determine whether the effects of native and acetylated forms of LDL are distinguishable by direct addition of lipidcontaining ECCM to culture, we examined the effects of various dilutions of ECCM prepared with $0-400 \mu \mathrm{g}$ of lipoproteins/ml. Fig. 4 shows that inhibitory lipid activity is partially reversed by dilution of ECCM. Medium prepared with 100 or $160 \mu \mathrm{g}$ of AcLDL/ml stimulates colony formation at dilutions of up to $\frac{1}{8} x$, whereas suppression by $400 \mu \mathrm{g}$ of AcLDL/ml persists at dilutions of up to $\frac{1}{4} x$ (see Fig. $4 \mathrm{~b}$ ). In contrast, both stimulatory and inhibitory activities are promptly ablated at a dilution of $\frac{1}{4} x$ for all concentrations of native LDL (see Fig. 4 $a$ ). While the dose-response curve with acetylated lipid is shifted in a predominantly vertical direction at increasing lipoprotein concentrations, it is shifted horizontally by increasing amounts of native lipoprotein. These distinct kinetics suggest that AcLDL and native LDL are acting through different mechanisms.

Delipidation of ECCM and enhancing activity. To explore the possibility that native and AcLDL operate by separate mechanisms to impair the expression of enhancing activity, we delipidated ECCM prepared from endothelial cells loaded with LDL, VLDL, or AcLDL. Fig. 5 shows that supranates of medium obtained by ultracentrifugation with solid $\mathrm{KBr}$ contain lipid, while infranates are virtually lipid free. When supranates and infranates of medium prepared from cells loaded with native LDL were assayed in culture, all of the inhibitory action was found to reside in supranates, while infranates expressed enhancing activity that was similar to that found in ECCM 

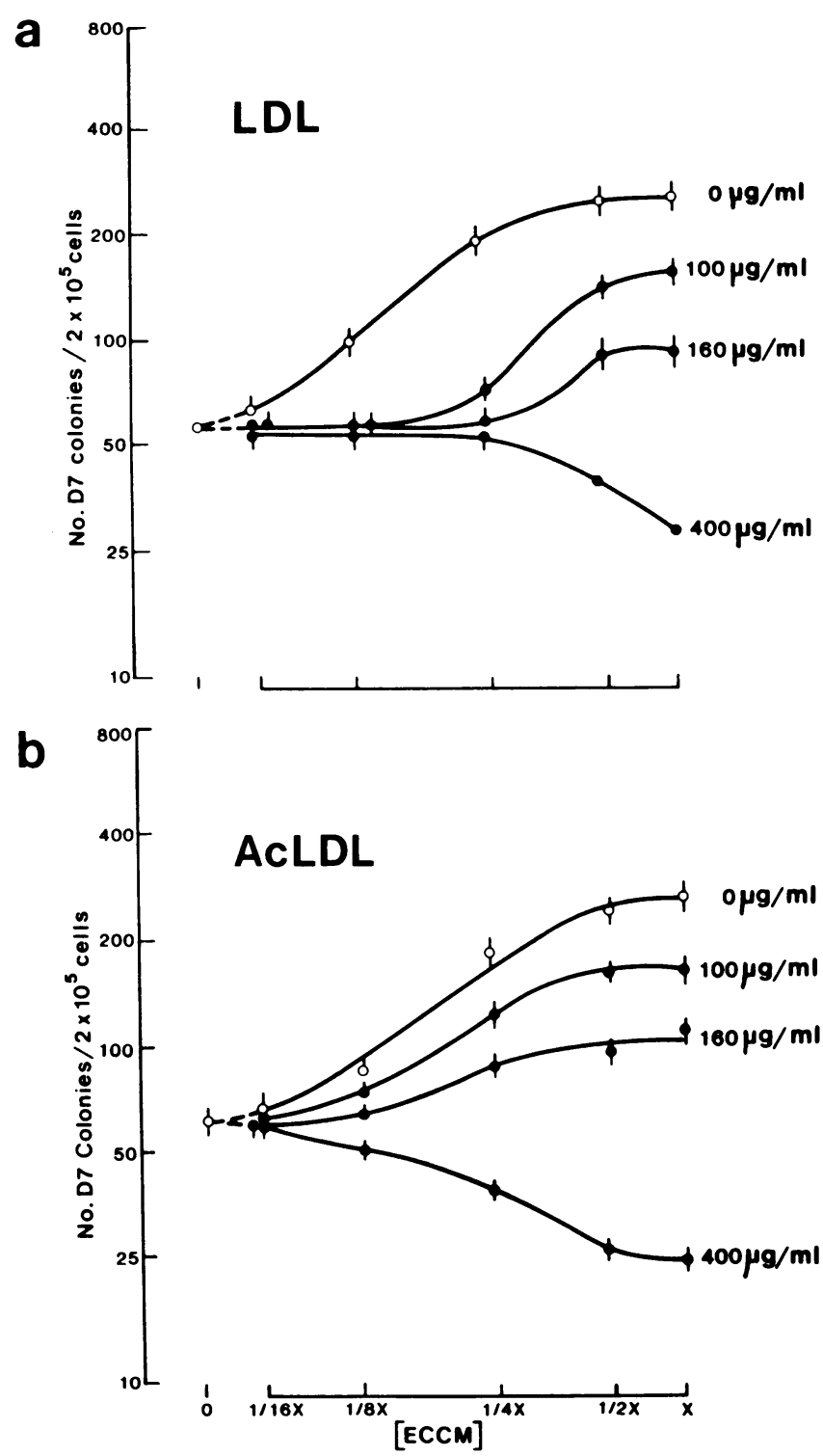

Figure 4. Reversal of lipid inhibitory activity. Mean \pm SE CFU-E-derived colonies are displayed for cultures containing $10 \%$ (vol/vol) ECCM at the indicated dilutions. Medium was prepared from BAEC incubated with the indicated amounts of native LDL $(a)$ or AcLDL (b). Marrow cultures contained $2.0 \mathrm{U} / \mathrm{ml}$ sheep erythropoietin. Note that in tests with ECCM from cells exposed to native LDL, dilution readily separates inhibitory activity from enhancing activity. In contrast, some suppression is seen at nearly all dilutions of ECCM prepared from AcLDL-exposed cells.

fractions prepared in the absence of lipid (see Fig. 6). In contrast, neither supranates nor infranates of AcLDL-loaded cells express enhancing activity (see Fig. 6). Because it is possible that low amounts ( $\leq 10 \%$ of the starting material) of AcLDL remained in the infranates, we measured the effects of 10,20 , 30 , and $40 \mu \mathrm{g} / \mathrm{ml} \mathrm{AcLDL}$ added directly to culture. No suppression of erythroid colony formation was observed at these concentrations $(102 \pm 4,98 \pm 5,110 \pm 10$, and $101 \pm 3 \%$ for day 7 colonies, respectively; and 107 $\pm 8,99 \pm 3,104 \pm 5$, and $102 \pm 3 \%$ for day 12 bursts, respectively). Furthermore, delipidation did not alter the growth promoting effects of ECCM prepared in the absence of lipid or with VLDL (Fig. 6).

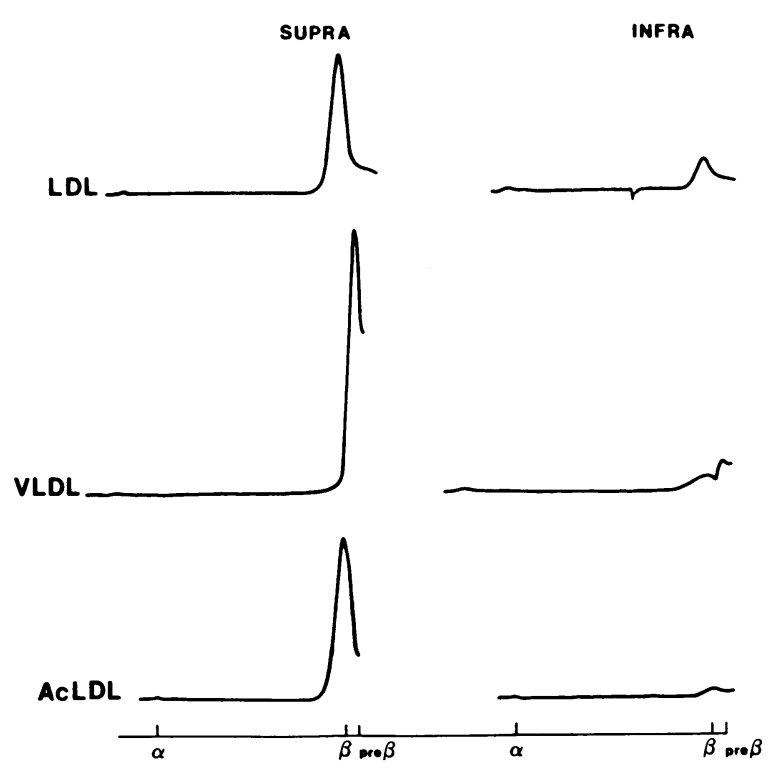

Figure 5. Delipidation of ECCM. Scans of gels stained with Sudan black are shown for supranates (supra) and infranates (infra) of ECCM obtained after centrifugation with $\mathrm{KBr}$. ECCM was prepared from BAEC incubated with LDL, VLDL, or AcLDL. Note that lipids are effectively localized to the supranate fraction in each case by this procedure.

Since lipids are present in the supranate fraction alone, our findings may be explained by a direct suppressive effect of native and AcLDL on erythroid colony formation plus an additional suppressive effect of AcLDL on the production or release of erythroid stimulatory molecules from endothelial cells. The latter finding is reminiscent of the reported effects of AcLDL on release of PDGF-like proteins by endothelial cells $(11,12)$.

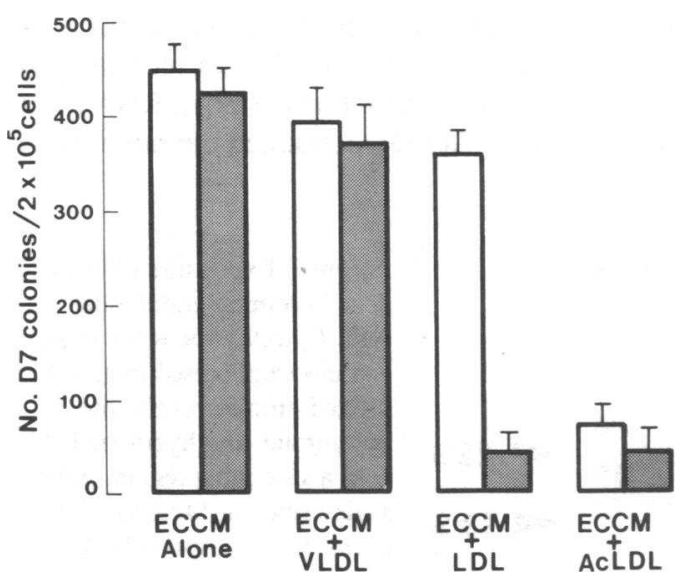

Figure 6. Effects of ECCM delipidation on growth enhancing activity. Mean \pm SE CFU-E-derived colonies are displayed for cultures containing $10 \%$ (vol/vol) supranates (solid bars) or infranates (open bars) of ECCM prepared from BAEC in the absence (ECCM alone) or presence of VLDL, LDL, or AcLDL ( $400 \mu \mathrm{g} / \mathrm{ml})$. Marrow cultures contained $2.0 \mathrm{U} / \mathrm{ml}$ sheep erythropoietin. Note that, while the lipid-free infranate of medium from LDL exposed cells expresses enhancing activity, that from AcLDL exposed cells is devoid of stimulatory activity. Similar results were obtained in cultures of erythroid BFU-Es and CFU-GEMMs (data not shown). 
Interactions of ECCM activity with other erythroid enhancers. We next assessed the possibility that the active endothelial cell molecule is PDGF. To determine whether these factors compete for the same biological effect, we assayed ECCM in marrow cultures with and without highly purified PDGF. The data in Fig. $2 b$ indicate that ECCM augments erythroid colony formation at each PDGF concentration. Similar results were observed in the plateau portion of the PDGF dose-response curve, suggesting that the erythroid enhancer in ECCM is additive with (and therefore biologically distinct from) PDGF.

Since bioactive molecules in ECCM may share antigens with erythroid BPA, we attempted to remove the active factor from ECCM by immunoabsorption with antimembrane IgG that removes soluble BPA from LCM (26). However, enhancing activity remained unchanged $(P>0.10)$ after absorption with 100 or $200 \mu \mathrm{g} \mathrm{IgG/ml,} \mathrm{followed} \mathrm{by} \mathrm{precipitation} \mathrm{with}$ staphylococcal Protein A (preabsorption burst stimulation, $160 \pm 8 \%$; postabsorption burst stimulation, $148 \pm 12$ and $154 \pm 10 \%$ for 100 and $200 \mu \mathrm{g} / \mathrm{ml}$, respectively). Together with our finding that stimulation by ECCM is present at a saturating LCM concentration (Fig. $2 a$ ), the data suggest that the active moiety in ECCM is not identical to erythroid BPA.

Influence of lipid loading on $\beta$-chain PDGF gene expression. Next, we investigated whether endothelial cells maintained under these various conditions of exposure to lipoproteins differentially express mRNA for the $\beta$-chain of PDGF. PDGF $\beta$ chain is encoded by the homologue (c-sis) of the simian virus transforming gene (v-sis) (33). Fig. 7 shows that a sis mRNA transcript is present in cytoplasmic RNA extracted from endothelial cells. This mRNA species was found in both lipid-loaded and control PHEC as well as in BAEC, and it was demonstrated in control human osteosarcoma cells but not in human dermal fibroblasts (Fig. 7).

To determine whether cholesterol loading has an effect on PDGF message, cDNA probe for v-sis homologue of PDGF was used to determine message levels in PHEC before and after incubation with AcLDL. As displayed in Fig. 8, the relative amounts of this transcript detectable by dot blot analysis were unchanged in two experiments. Furthermore, RNA from cells incubated for $7 \mathrm{~d}$ with AcLDL contained the same levels

\section{HEC FIB HOS}

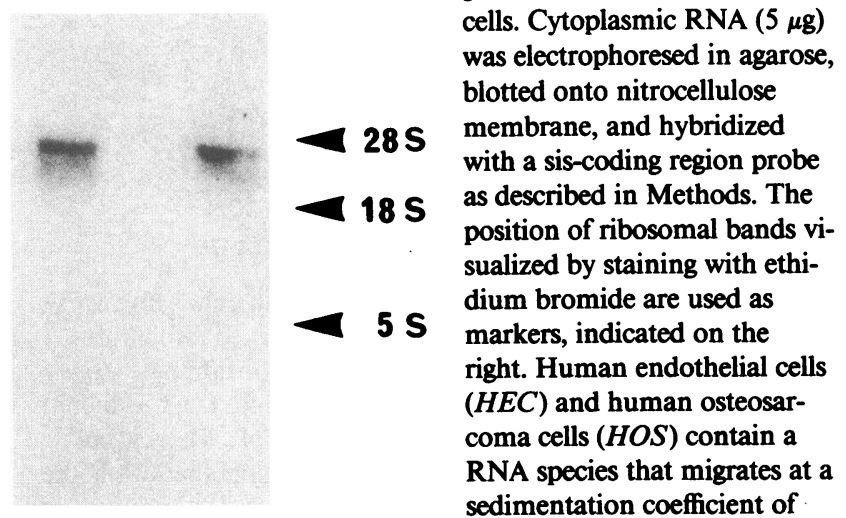

$\sim 25 \mathrm{~S}$, corresponding to $\sim 3.7$ kilobases, and hybridizes specifically with the sis probe, whereas RNA from human dermal fibroblasts (FIB) does not.

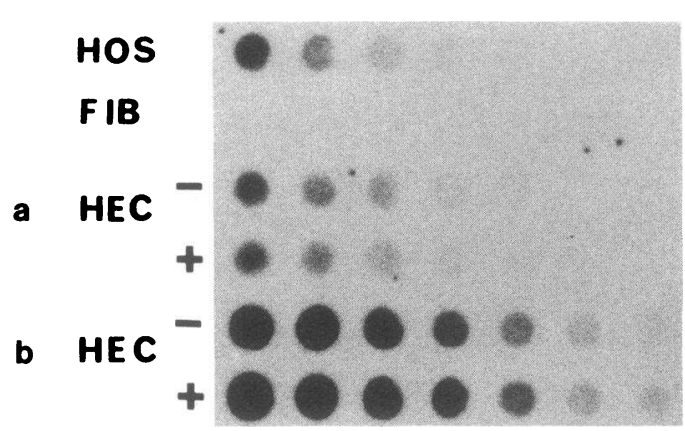

Figure 8. Effects of AcLDL on sis levels in endothelial cells. The dot blot compares sis RNA levels in human endothelial cells (HEC) incubated with (+) and without (-) 300-450 $\mu \mathrm{g}$ of AcLDL/ml. PHEC RNA from the separate experiments $(a$ and $b$ ) were serially diluted $1: 1$. In each experiment, no significant difference in the relative amounts of specific $\beta$-chain PDGF transcripts were noted. (a) $25 \mu \mathrm{g}$ of RNA was serially diluted after exposure to AcLDL or control, 48 $\mathrm{h}$, resulting in $77 \%$ increase in cell cholesterol in the lipid-exposed cells; (b) $50 \mu \mathrm{g}$ of RNA was serially diluted after exposure to AcLDL, $20 \mathrm{~h}$, resulting in a 32\% increase in cell cholesterol in the lipid-exposed cells. Human osteosarcoma cells $(H O S)$ and human dermal fibroblasts $(F I B)$ are positive and negative controls, respectively.

of sis transcript that were detectable at $24 \mathrm{~h}$ of incubation. Similar results were obtained with BAEC.

To determine the effects of lipid loading upon the levels of PDGF protein secreted from endothelial cells, immunoprecipitation of ECCM after metabolic labeling with $\left[{ }^{35}\right.$ S]cysteine was performed. Autoradiograms were scanned by laser densitometry to determine the relative amounts of PDGF from lipid-loaded and control cells expressed as the area under each peak. Fig. 9 shows that the degree of cholesterol loading did not influence secretion of metabolically labeled PDGF by endothelial cells. This observation complements our result showing that cholesterol loading does not alter the level of $\beta$-chain PDGF transcription, and is consistent with our finding that mitogenic activity for smooth muscle cells is likewise unaltered in ECCM by cholesterol loading (data not shown).

Preliminary characterization of ECCM activity. Initial characterization of the activity in ECCM included testing for sensitivity to a reducing agent and to heat exposure. Enhancing activity was expressed at the same level in the presence and absence of L-asparagine, 3-mercapto-1,2-propanediol (from a

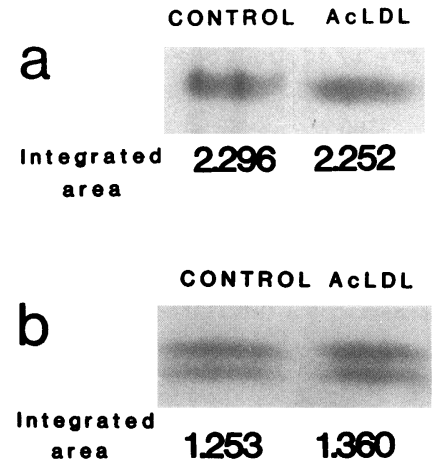

Figure 9. Immunoprecipitation of ${ }^{35}$ S $]$ cysteine-labeled endothelial cell-derived PDGF secreted into culture medium in the absence or presence of AcLDL. Specific PDGF bands in the nonreduced form, migrating at $30 \mathrm{kD}(a)$, and the reduced form, migrating as a doublet at $15 \mathrm{kD}(b)$, are shown. Autoradiograms were scanned with a laser densitometer and the integrated area of the peaks (arbitrary units) were compared. There were no significant differences between secreted PDGF levels in the presence and absence of $250 \mu \mathrm{g}$ of AcLDL/ml. Total cellular cholesterol was increased to $166 \%$ of control by exposure to AcLDL in this experiment. 
control level of $33 \pm 3$ to $164 \pm 10$ and $157 \pm 6$ CFU-E-derived colonies $/ 2 \times 10^{5}$ cells, respectively). Moreover, ECCM was inactivated by heat exposure using conditions under which PDGF erythroid growth stimulatory activity is known to be retained (13) (see Table IV).

To determine the approximate size of the active erythroid enhancing molecules in ECCM, preparative SDS gel electrophoresis was performed. Fig. 10 shows that maximum colonystimulating activity was eluted in two of the gel slices containing molecules with reduced molecular masses of 75,000105,000 daltons (slice 3) and 105,000-160,000 daltons (slice 2).

\section{Discussion}

As a structural component of nuclear, mitochondrial, and plasma membranes, cholesterol is critical to maintaining mechanical stability of all eukaryotic cells (34). Recently, we have suggested that endogenous cholesterol synthesis may be important for maintenance of proliferating human erythroid progenitor cells in serum-free culture (20). Blockage of cholesterol synthesis in mammalian cells in vitro results in profound effects on a variety of cell functions, including differentiation and cell fusion (35-38). While most cultured cells synthesize cholesterol even in the presence of serum $(39,40)$, the role played by exogenous cholesterol as a nutrient for cell growth is also well recognized (41). Here, we have studied the influence of exogenous cholesterol on the release of growth-enhancing molecules from human and bovine endothelial cells. We show that when cultured endothelium is incubated with acetylated LDL as a source of exogenous cholesterol, hematopoietic growth factor release is markedly impaired. Suppression is not explained by an effect of LDL per se since delipidation of ECCM before addition to hematopoietic culture does not reverse the inhibitory action of acetylated LDL (Figs. 5 and 6). Furthermore, stimulatory and inhibitory activities are readily separated by dilution of ECCM prepared with native LDL but not of that prepared with acetylated LDL (see Fig. 4). Our findings suggest that cholesterol loading of endothelial cells with acetylated but not with native LDL interferes with release of the growth-enhancing factor. The biochemical mechanism

Table IV. Heat Inactivation of ECCM

\begin{tabular}{lrrrr}
\hline & \multicolumn{4}{c}{ Colony stimulation } \\
\cline { 2 - 5 } \multicolumn{1}{c}{ ECCM treatment } & $\begin{array}{c}\text { Day 7 } \\
\text { erythroid }\end{array}$ & $\begin{array}{c}\text { Day 12 } \\
\text { erythroid }\end{array}$ & Mixed & G/M \\
\hline & & \multicolumn{4}{c}{$\%$} & \\
None & $283 \pm 18$ & $405 \pm 30$ & $274 \pm 21$ & $265 \pm 18$ \\
Heat $\left(100^{\circ} \mathrm{C}, 10 \mathrm{~min}\right)$ & $120 \pm 17$ & $88 \pm 15$ & $125 \pm 19$ & $116 \pm 10$ \\
\hline
\end{tabular}

Mean \pm SE stimulation in quadruplicates is shown in three studies relative to cultures containing $10 \%$ ( $\mathrm{vol} / \mathrm{vol}$ ) base medium. Erythroid and mixed colony cultures contained $2.0 \mathrm{IU} / \mathrm{ml}$ sheep erythropoietin and $10 \% \mathrm{LCM}$. Myeloid cultures contained $5 \mathrm{ng}$ of CSF/ml plus ECCM. Stimulatory activity in ECCM prepared from bovine endothelium for CFU-E, BFU-E, CFU-GEMM, and CFU-GM proliferation is reduced after exposure to heat $(P<0.01$ for each). Cultures with $100 \%$ stimulation contained 68 CFU-E-derived, 34 BFU-E-derived, 18 CFU-GEMM-derived, and 47 CFU-G/M derived colonies per clot.
Figure 10. Activity profile of electroeluted growth factor. ECCM was prepared from BAEC under serum-free

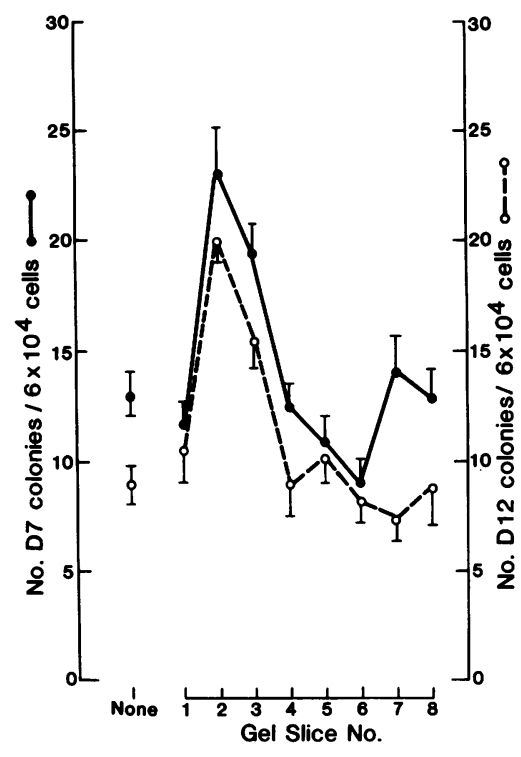
conditions and electrophoresed on $10 \%$ polyacrylamide gels. The gel was sliced into $1-\mathrm{cm}$ fractions containing molecules with molecular masses of $<55,000$ (slices 5-8), 55,00075,000 (slice 4), 75,000-105,000 (slice 3), 105,000-160,000 (slice 2), and > 160,000 daltons (slice 1). Bioassay shows that stimulatory activity for CFU-E $(\bullet)$ and BFU-E (o) proliferation is localized primarily to gel fractions 3 and 2. Means \pm SE are displayed.

by which acetylation alters endothelial cell secretion is unknown. Recently, however, Fox et al. have suggested that oxidation of AcLDL may impair PDGF production by endothelial cells (12).

Our results confirm that endothelial cells release hematopoietic growth-promoting factors (2-5). Because the proliferation of CFU-G/Ms and CFU-GEMMs, as well as BFU-Es and CFU-Es, is increased by ECCM (Table I and Fig. 1), the state of differentiation of the marrow stem cell is not critical for an enhancing effect. While the erythropoietic stimulatory activity(ies) has not been purified to homogeneity, several conclusions may be drawn suggesting that its biological function is distinct among this group of growth-promoting factors. First, ECCM activity does not supplant that of erythropoietin or LCM since hematopoietic colonies do not appear in culture unless erythropoietin and (in the case of CFU-GEMM-derived colonies) LCM or IL-3 are added to culture. Furthermore, its erythropoietic activity is expressed at all erythropoietin, LCM, and IL-3 concentrations, indicating that its action is additive with that of each of these agents. Our finding that the erythropoietic activity is not immunoprecipitable with antibodies that recognize BPA or recombinant GM-CSF supports this contention. In addition, ECCM does not alter ${ }^{59} \mathrm{Fe}$ incorporation in the hypertransfused, polycythemic mouse bioassay, and, therefore, does not express the in vivo biological activity of erythropoietin (data not shown).

Next, the enhancing factor behaves as a non-PDGF molecule. Its sensitivity to heat $\left(100^{\circ} \mathrm{C}, 10 \mathrm{~min}\right)$ and its resistance to thiol-containing compounds suggest that it is biochemically distinct from PDGF. Unlike PDGF, it comigrates with molecules having a molecular mass of 75,000-160,000 daltons on preparative SDS gels. Results of studies in coculture with highly purified PDGF suggest that its activity is additive with that of human and porcine PDGF. Moreover, although acetylated LDL impair the release of the factor $(11,12)$, levels of endothelial cell mRNA for the $\beta$-chain of PDGF as well as secretion of immunologically precipitable PDGF are similar 
under lipid-loaded and control conditions (42; see also Figs. 8 and 9). Together, the data strongly suggest that the hematopoietic EDGF is a non-PDGF molecule. On the one hand, candidates for the active moiety include novel as well as previously described growth factors, including GM-CSF-like molecules which may act as multilineage hematopoietins (43) and which have been recently described to be produced by cultured human endothelium using a CDNA probe to human GM-CSF (44). Stimulation of erythroid burst formation by a crude CSF preparation (Fig. $2 b$ ) is consistent with this possibility. On the other hand, lack of immunologic cross-reactivity with a human recombinant GM-CSF preparation suggests that a unique erythropoietic factor may be present. Purification of the active component(s) in ECCM is in progress.

Our observation that native LDL suppress hematopoietic colony formation concurs with previous reports showing that this lipoprotein fraction of serum is inhibitory to hematopoietic progenitor proliferation (45-47). Although the cellular mechanism for LDL suppression is unknown, our approach may be applicable to the study of this phenomenon since serum LDL are known to inhibit a number of lymphocyte responses, including generation of an immune response and lymphoproliferation both in vitro and in vivo (37-49). Because hematopoietic growth-promoting molecules are released from peripheral blood mononuclear cells $(25,50-52)$, it is possible that LDL alter interactions among various lymphocyte and/or monocyte populations and other cell types, including hematopoietic progenitor cells and endothelial cells. Such interactions have been reported to be important in the generation of multilineage and granulocyte/macrophage colony-stimulating activities from cultured endothelial cells (53-57). Our findings underscore the importance of carefully defining the medium in which endothelial cells are maintained. For example, detection of growth factor release by endothelial cells in the absence of monocyte-derived products may require serum-free hematopoietic culture conditions. In this respect, the in vitro effects of endothelial cell-derived enhancing factors may be similar to those of classic hormones and PDGF (58).

In summary, our results suggest that endothelial cells are a source of hematopoietic growth-enhancing molecules whose release is abrogated by cholesterol loading using AcLDL as a vehicle. These molecules, which appear to be distinct from other well characterized hematopoietic growth factors, may be directly mitogenic for progenitor cells or may replace growth factors for nonhematopoietic cells that are normally present in the marrow microenvironment. Studies employing a purified EDGF molecule will be useful in defining the precise mechanism by which acetylated lipoproteins interfere with growth factor release.

\section{Acknowledgments}

We are grateful to Chris Cannon, Pip Diehl, Joseph Connolly, and Paula Ferro for technical assistance; Dr. S. Clark (Genetics Institute) for providing recombinant human GM-CSF, rHSIL-3, and antihuman rGM-CSF antiserum; Joan Joos for preparing the art work; and Donna MacDonald for typing this manuscript.

This work was supported by part by research grants AM-27071 and AM-31060 to Dr. Dainiak, HL-36028 and HL-36049 to Dr. Davies, and HL-28749 to Dr. Lawler, all from the National Institutes of Health, and by a grant to Dr. Warren from the American Heart Association.

\section{References}

1. Weiss, L. 1984. The Blood Cells and Hematopoietic Tissues. 2nd edition. Elsevier Science Publishing Co., Inc., New York. 502-509.

2. Quesenberry, P. J., and M. A. Gimbrone Jr. 1980. Vascular endothelium as a regulator of granulopoiesis: production of colonystimulating activity by cultured endothelial cells. Blood. 56:10601067.

3. Galelli, A., A. M. Dosne, A. Morin, F. Dubor, and L. Chedid. 1985. Stimulation of human endothelial cells by synthetic muramyl peptides: production of colony-stimulating activity (CSA). Exp. Hematol. 13:1157-1163.

4. Gordon, M. Y., L. Kearney, and J. A. Hibbin. 1983. Effects of human marrow stromal cells on proliferation by human granulocytic (GM-CFC), erythroid (BFU-E) and mixed (Mix-CFC) colony forming cells. Br. J. Haematol. 53:317-325.

5. Ascensao, J. L., G. M. Vercellotti, H. S. Jacob, and E. D. Zanjani. 1984. Role of endothelial cells in human hematopoiesis: modulation of mixed colony growth in vitro. Blood. 63:553-558.

6. Ross, R., J. Glomset, B. Kariya, and L. Harker. 1974. A platelet-dependent serum factor that stimulates the proliferation of arterial smooth muscle cells. Proc. Natl. Acad. Sci. USA. 71:1207-1210.

7. Kohler, N., and A. Lipton. 1974. Platelets as a source of fibroblast growth-promoting activity. Exp. Cell. Res. 87:297-301.

8. Davies, P. F., and R. Ross. 1978. Mediation of pinocytosis in cultured arterial smooth muscle and endothelial cells by platelet-derived growth factor. J. Cell Biol. 79:663-671.

9. Scher, C. D., R. C. Shepard, N. H. Antoniades, and C. D. Stiles. 1979. Platelet-derived growth factor and the regulation of the mammalian cell cycle. Biochim. Biophys. Acta. 560:217-241.

10. DiCorleta, P. E., and D. F. Bowen-Pope. 1983. Cultured endothelial cells produce a platelet-derived growth factor-like protein. Proc. Natl. Acad. Sci. USA. 80:1919-1923.

11. Fox, P. L., and P. E. DiCorleto. 1986. Modified low density lipoproteins suppress production of a platelet-derived growth factorlike protein by cultured endothelial cells. Proc. Natl. Acad. Sci. USA. 83:4774-4778.

12. Fox, P. L., G. M. Chisolm, and P. E. DiCorleto. 1986. Production of PDGF-like protein by endothelial cells is inhibited by oxidized lipoproteins. J. Cell Biol. 103:17a. (Abstr.)

13. Dainiak, N., G. Davies, M. Kalmanti, J. Lawler, and V. Kulkarni. 1983. Platelet-derived growth factor promotes proliferation of erythropoietic progenitor cells in vitro. J. Clin. Invest. 71:1206-1214.

14. Delwiche, F., E. Raines, J. Powell, R. Ross, and J. Adamson. 1985. Platelet-derived growth factor enhance in vitro erythropoiesis via stimulation of mesenchymal cells. J. Clin. Invest. 76:137-142.

15. Thornton, S. C., S. N. Mueller and E. M. Levine. 1983. Human endothelial cells: use of heparin in cloning and long-term serial cultivation. Science (Wash. DC). 222:623-625.

16. Davies, P. F., G. A. Truskey, H. B. Warren, S. E. O'Connor, and B. H. Eisenhaure. 1985. Metabolic cooperation between vascular endothelial cells and smooth muscle cells in co-culture: changes in low density lipoprotein metabolism. J. Cell Biol. 101:871-879.

17. Fraenkel-Conrat, H. 1957. Methods for investigating the essential groups for enzyme activity. Methods Enzymol. 4:247-269.

18. Hatch, F. T., and R. S. Lees. 1968. Practical methods for plasma lipoprotein analysis. Adv. Lipid Res. 6:1-68.

19. Heider, J. G., and R. L. Boyett. 1978. The picomole determination of free and total cholesterol in cells in culture. J. Lipid Res. 19:514-519.

20. Dainiak, N., S. Kreczko, A. Cohen, R. Pannell, and J. Lawler. 1985. Primary human marrow cultures for erythroid bursts in a serum-substituted system. Exp. Hematol. 13:1073-1079.

21. Dainiak, N., D. Sutter, and S. Kreczko. 1986. L-triiodothyronine augments erythropoietic growth factor release from peripheral blood and bone marrow leukocytes. Blood. 68:1289-1297.

22. Dainiak, N., and C. M. Cohen. 1982. Surface membrane vesi- 
cles from mononuclear cells stimulate erythroid stem cells to proliferate in culture. Blood. 60:583-594.

23. Stroobant, P., and M. D. Waterfield. 1984. Purification and properties of porcine platelet-derived growth factor. $E M B O$ (Eur. Mol. Biol. Organ.) J. 12:2963-2967.

24. Laemmli, U. K. 1970. Cleavage of structural proteins during the assembly of the head of bacteriophage T4. Nature (Lond.). 227:680-682.

25. Hunkapiller, M. W., E. Lujan, F. Ostrander, and L. E. Mood. 1983. Isolation of microgram quantities of proteins from polyacrylamide gels for amino acid sequence analysis. Methods Enzymol. 91:227-236.

26. Dainiak, N., L. Feldman, and C. M. Cohen. 1985. Neutralization of erythroid burst promoting activity in vitro with antimembrane antibodies. Blood. 65:877-885.

26a. Feldman, L., C. M. Cohen, M. A. Riordan, and N. Dainiak. 1987. Purification a membrane-derived human erythroid growth factor. Proc. Natl. Acad. Sci. USA. 84:6775-6779.

27. Yang Y-C., A. B. Ciarletta, P. A. Temple, M. P. Chung, S. Kovacic, J. S. Witek-Giannotti, A. C. Leary, R. Kriz, R. E. Donahue, G. G. Wong, and S. C. Clark. 1986. Human Il-3 (multi-CSF): identification by expression cloning of a novel hematopoietic growth factor related to murine Il-3. Cell. 47:3-10.

28. Favaloro, J., R. Treisman, and R. Kanen. 1980. Transcription maps of polyoma virus-specific RNA: analysis by two-dimensional nuclease S-1 gel mapping Methods Enzymol. 65:718-749.

29. Maniatis, T., E. F. Fritch, and J. Sambrook. 1982. Molecular Cloning: A Laboratory Manual. Cold Spring Harbor Laboratory, Cold Spring Harbor, NY. 202.

30. Maniatis, T., E. F. Fritch, and J. Sambrook. 1982. Molecular Cloning: A Laboratory Manual. Cold Spring Harbor Laboratory, Cold Spring Harbor, NY. 201.

31. White, B. A., and F. C. Bancroft. 1982. Cytoplasmic dot hybridization. J. Biol. Chem. 257:8569-8572.

32. Goldstein, A. 1964. Biostatistics: An Introductory Text. Macmillan, New York. 62.

33. Doolittle, R. F., M. W. Hunkapiller, L. E. Hood, S. G. Devare, K. C. Robbins, S. A. Aaronson, and H. A. Antoniades. 1983. Simian sarcoma virus oncogene, v-sis, is derived from the gene (or genes) encoding a platelet-derived growth factor. Science (Wash. DC). 221:275-277.

34. Alberts, B., D. Bray, J. Lewis, M. Raff, K. Roberts, and J. D. Watson. 1983. Molecular Biology of the Cell. Garland Publishing Co., New York. 259-264.

35. Maltese, W. A., B. A. Reitz, and J. J. Volpe. 1981. Effects of prior sterol depletion on neurite outgrowth in neuroblastoma cells. $J$. Cell. Physiol. 108:475-482.

36. Horwitz, A. F., A. Wight, P. Ludwig, and R. Cornell. 1978. Interrelated lipid alterations and their influence on the proliferation and fusion of cultured myogenic cells. J. Cell Biol. 77:334-357.

37. Heiniger, H.-J., K. T. Brunner, and J.-C. Cerottini. 1978. Cholesterol is a critical component for T-lymphocyte cytotoxicity. Proc. Natl. Acad. Sci. USA. 75:5683-5687.

38. Chen, S. S. 1979. Enhanced sterol synthesis in concanavalin A-stimulated lymphocytes: correlation with phospholipid synthesis and DNA synthesis. J. Cell. Physiol. 100:147-158.

39. Chen, H. W., and A. A. Kandutsch. 1981. Cholesterol requirements for cell growth: endogenous versus exogenous sources. In The Growth Requirements of Vertebrate Cells In Vitro. C. Waymouth, R. G. Ham, and P. J. Chapple, editors. Cambridge University Press, Cambridge. 327-342.

40. Kandutsch, A. A., H. W. Chen, and H.-J. Heiniger. 1978 Biological activity of some oxygenated sterols. Science (Wash. DC). 201:498-501.
41. Chen, H. W. 1984. Role of cholesterol metabolism in cell growth. Fed. Proc. 43:126-130.

42. Warren, H. B., T. Collins, and P. F. Davies. 1986. C-sis RNA expressed by cholesterol loaded bovine aortic endothelial cells. Fed. Proc. 45:1073.

43. Metcalf, D., G. R. Johnson, and A. W. Burgess. 1980. Direct stimulation by purified GM-CSF of the proliferation of multipotential and erythroid precursor cells. Blood. 55:138-147.

44. Sieff, C. A., S. Tsai, and D. V. Faller. 1987. Interleukin-1 induces cultured human endothelial cell production of granulocytemacrophage colony-stimulating factor. J. Clin. Invest. 79:48-51.

45. Granstrom, M. 1972. Studies on inhibitors of marrow colony formation in normal human sera and during a viral infection. Exp. Cell. Res. 87:426-431.

46. Zucker, S., M. S. Michael, R. M. Lysik, H. J. Glucksman, J. Reese, and A. Rendin 1979. Lipoprotein inhibition of bone marrow cells in tumor-bearing rats. Cell. Tissue. Kinet. 17:393-399.

47. Douay, L., B. Veronique, C. Baillou, A. Najman, N.-C. Gorin, J. Polonovski and G. Duhamel. 1983. The role of serum lipoproteins on the in vitro proliferative potential of human hematopoietic progenitors CFU-C and CFU-E. Exp. Hematol. 11:499-505.

48. Waddell, C. C., D. Taunton, and J. J. Twomey. 1976. Inhibition of lymphoproliferation by hyperlipoproteinemic plasma. J. Clin. Invest. 58:950-954.

49. Curtiss, L. K., D. H. DeHeer, and T. S. Edgington. 1980. Influence of the immunoregulatory serum lipoprotein LDL-In on the in vivo proliferation and differentiation of antigen-binding and antibody-secreting lymphocytes during a primary immune response. Cell. Immunol. 49:1-11.

50. Zuckerman, K. S. 1981. Human erythroid burst-forming units: growth in vitro is dependent on monocytes but not T-lymphocytes. $J$. Clin. Invest. 67:702-709.

51. Linch, D. C., and D. G. Nathan. 1984. T cell and monocyte-derived burst-promoting activity directly act on erythroid progenitor cells. Nature (Lond.). 312:775-777.

52. Najman, A., C. Baillou, X. Drouet, G. LeBlanc, L. Donay, N. C. Gorin, and G. Duhamel. 1985. Regulation of human peripheral blood BFU-E growth in vitro by leukaemic B-lymphocytes. $\mathrm{Br}$. $J$. Haematol. 60:643-648.

53. Bagby, G. C., E. McCall, K. A. Bergstrom, and D. Burger. 1983. A monokine regulates colony-stimulating activity production by vascular endothelial cells. Blood. 62:663-668.

54. Zuckerman, K. S., G. C. Bagby, E. McCall, B. Sparks, J. Wells, V. Patel, and D. Goodrum. 1985. A monokine stimulates production of human erythroid burst-promoting activity by endothelial cells in vitro. J. Clin. Invest. 75:722-725.

55. Broudy, V. C., K. Kaushansky, G. M. Segal, J. M. Harlan, and J. W. Adamson. 1986. Tumor necrosis factor type alpha stimulates human endothelial cells to produce granulocyte/macrophage colonystimulating factor. Proc. Natl. Acad. Sci. USA. 83:7467-7471.

56. Bagby, G. C., C. A. Dinarello, P. Wallace, C. Wagner, S. Hefeneider, and E. McCall. 1986. Interleukin-1 stimulates granulocyte macrophage colony-stimulating activity release by vascular endothelial cells. J. Clin. Invest. 78:1316-1323.

57. Zsebo, K., V. Yuschenkoff, M. Fox, S. Schiffer, E. McCall, D. Chang, G. Bagby, and B. Altrock. 1986. Interleukin-1 stimulates the production of G-CSF and GM-CSF by endothelial cells in vitro. Blood. 68:185a. (Abstr.)

58. Dainiak, N., 1985. Role of defined and undefined serum additives to hematopoietic stem cell culture. In Hematopoietic Stem Cell Physiology. E. P. Cronkite, N. Dainiak, R. P. McCaffrey, J. Palek, and P. J. Quesenberry, editors. Alan R. Liss, Inc. New York. 59-76. 